\title{
Yield Gap Analysis through Cluster Front Line Demonstrations on Blackgram in Hamirpur District of Himachal Pradesh, India
}

\author{
Dhanbir Singh* \\ Department of Soil Science, CSK Himachal Pradesh Krishi Vishvavidyalaya, \\ Palampur (H.P.), India \\ *Corresponding author
}

\section{A B S T R A C T}

\section{Keywords}

Blackgram,

Extension gap, Technological gap, B: C ratio

\section{Article Info}

Accepted:

17 October 2020

Available Online:

10 November 2020
The present study was undertaken to evaluate the yield gap through CFLDs on blackgram by the active participation of farmers with the objective to harness maximum potential of crops by demonstrating the improved technologies. Krishi Vigyan Kendra, Hamirpur (H.P.) conducted 88 demonstrations on blackgram (Vigna mungo L., Fabaceae) in 16.7 ha area during kharif 2016 and 2017 in different villages of district Hamirpur, Himachal Pradesh. Prevailing farmers' practices were treated as control for comparison with recommended practices. During kharif 2016 2017, the average yield of blackgram variety Him Mash-I was recorded to be 6.31 and $7.54 \mathrm{qha}^{-1}$ and that of UG-218 was 5.4 and 6.77 $\mathrm{qha}^{-1}$, respectively. The increase in average yield of Him Mash-I over control i.e. farmers practice (Local Mash) was 30.8 and 21.2 percent in 2016 and 2017while in UG-218 was 14.2 and 9.1 per cent over control for the respective years. The average technology gap in Him Mash-I was recorded to be 5.69 and $4.46 \mathrm{q} \mathrm{ha}^{-1}$ in 2016 and 2017, respectively and 4.60 and $3.23 \mathrm{q} \mathrm{ha}^{-1}$ in UG-218 in the corresponding years. The respective extension gap was calculated to be1.47 and $1.32 \mathrm{q} \mathrm{ha}^{-1}$ in Him Mash-I and 0.67 and 0.57 in UG-218 in 2016 and 2017. The technology index (\%) was found to be 47.4 and 37.2 in Him MashIand 46 and 32.3 per cent in UG-218 during kharif 2016 \& 2017, respectively.

\section{Introduction}

India is the largest producer of pulses, accounting for 25 per cent of global pulses production. In a country like India, pulses are the cheapest and concentrated source of dietary amino acids, where protein demand of vegetarian population is fulfilled through pulses, so it is also considered as "A poor man's meat". Pulses occupy a distinctive position in the world of agriculture by virtue of its high protein content, which is almost double than that of cereals. In addition to proteins, pulses also contain good quality lysine, tryptophan, ascorbic acid and riboflavin. Pulse crops are considered as the wonderful gift of nature as they have an ability to fix the atmospheric nitrogen $\left(\mathrm{N}_{2}\right)$, thereby helps in $\mathrm{N}$ cycling within the ecosystem. Besides $\mathrm{N}_{2}$ fixation, incorporation of pulse crop residue increases the microbial activity, restores soil properties in soil and carbon sequestration, and thus provides sustainability in crop production system 
(Singh et.al, 2016). Pulses on account of their vital role in nutritional security and soil amelioration have been a fundamental part of sustainable agriculture since ages. Black gram (Vigna mungo L.) is a widely grown legume, belongs to the family fabaceae and assumes considerable importance in terms of food and nutritional security in the world. It is a short duration crop and thrives better in all seasons either as sole or as intercrop.

Blackgram is one of the important pulse crops grown throughout India and is consumed in the form of 'dal' (whole or split, husked and un-husked). India is the world's largest producer as well as consumer of black gram. It produces about 1.5-1.9 metric tonnes of black gram annually from about $3.5 \mathrm{~m}$ ha of area, with an average productivity of $600 \mathrm{~kg}$ $\mathrm{ha}^{-1}$.

Black gram output accounts for about 10 per cent of India's total pulse production. It is therefore, necessary to assess the technological gap in production and also to know the problems and constraints in adopting modern black gram production technologies Islam et al (2011).

The main objective of front line demonstrations (FLDs) was to show the worth or value of the technology. To minimize the adoption gap and increase the productivity, FLDs can play acritical role. The general objectives of frontline demonstration is "to demonstrate under farmer's field condition, the superior production, potentials and benefits of the latest improved technologies including new production technologies, high yielding crop varieties and recommendations for different regions, agro ecological crop growing situation vis-à-vis traditional practices. The present investigation was undertaken for analysis of Cluster Front Line Demonstrations (CFLD's) on blackgram in Hamirpur district of Himachal Pradesh.

\section{Materials and Methods}

Frontline demonstrations (FLDs) on improved farm technology were conducted by CSK, Himachal Pradesh Krishi Vishavavidyalaya Palampur Krishi Vigyan Kendra, Hamirpur. A total no. of 88 demonstrations in a 16.7 ha area was conducted on blackgram during kharif 2016 and 2017 in different villages of the district. Before conducting FLDs, a list of farmers was prepared from group meeting and specific skill training was imparted to the selected farmers regarding package of practices of scientific pulse production techniques. The difference between demonstration package and existing farmers practices are given in Table 1 .

In general, the soils under study were sandy loam to loamy sand in texture with a $\mathrm{pH}$ range in between 6.4 to 7.6. The available nitrogen, phosphorus and potassium varied between $210-315,12-19$ and $165-236 \mathrm{~kg} \mathrm{ha}^{-1}$, respectively. In demonstration plots, use of quality seeds of improved varieties, timely weeding, need based application of pesticides as well as balanced fertilization were emphasized and comparison was made with the existing practices (Table 1). The necessary steps for the selection of site and farmers, lay out of demonstrations etc. were followed as suggested by Chaudhary (1999). The traditional practices were maintained in case of local check. The data output were collected from both FLD plots as well as control plots. The primary data on grain yield and farmers' practices was collected from the beneficiary farmers through random plot cutting methodology followed by personal interviews. The increase in yield demonstrations over farmers' practice was calculated by using the following formula.

\footnotetext{
\% yield increase over farmers practice (\%YIOFP) $=$

Demonstration plot average yield-farmers plot average yield Farmers plot average yield 
Estimation of technology gap, extension gap and technology index

The estimation of technology gap, extension gap and technology index was done using formulae given by Kadian et al., (1997) and Samui et al., (2000) as under:

i) Technology gap = Potential yieldDemonstrations plot average yield.

ii) Extension gap $=$ Demonstrations plot average yield-Farmers plot average yield.

iii) Technology Index $=(\mathrm{Pi}-\mathrm{Di})$

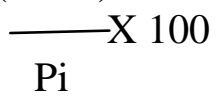

Where, $\mathrm{Pi}=$ potential yield of $\mathrm{i}^{\text {th }}$ crop

$\mathrm{Di}=$ Average demonstrations plot yield of $i^{\text {th }}$ crop.

\section{Economic analysis}

The analysis of demonstration plots was done for calculating gross returns, cost of cultivation, net returns and benefit: cost ratio. Cost of cultivation of pulses mainly included cost of inputs like seed, fertilizers and pesticides purchased by the farmers in farmers practice (FP) or demonstrated by the Kendra in demonstrations practice along with hired labour, sowing charges of tractor/bullocks, inter-culture operations and harvesting charges. The gross and net returns and benefit cost ratio were calculated as under:

Gross returns $=$ Grain yield $\mathrm{x}$ pulse sale price

Net returns $=$ Gross returns- Cost of cultivation

$\mathrm{B}: \mathrm{C}=$ Gross returns/cost of cultivation .

\section{Results and Discussion}

The results and discussions of the study on the yield performance, technology gap, extension gap, technology index and economic returns are presented below:

\section{Yield performance}

The data depicted in Table 2 revealed that the seed yield of blackgram increased successively during kharif 2016 and 2017 in demonstration plots with average yield of blackgram variety Him Mash-I recorded as 6.31 and $7.54 \mathrm{qha}^{-1}$ and that of blackgram variety UG-218 as 5.4 and6.77 qha $^{-1}$ respectively. In the farmers practice (local check), yield obtained was 4.84 and 6.22 in Him Mash-I and 4.73 and 6.22 in UG-218 during 2016 and 2017, respectively. The seed yield in CFLD's was higher as compared to local check during both the years of study. This may be due to improved varietal seed, right time of sowing, seed treatment, line sowing, nutrient management, need based plant protection measures and time to time technical guidance followed as compared to farmers' practice.

There was less yield of both blackgram varieties during kharif 2016 as compared to kharif 2017most likely due to delayed monsoon rains at the time of maturity. The percent increase in yield over farmers' practice (local mash) was 30.8 and 21.2 in Him Mash-I and 14.2 and 9.1 per cent in UG218 in 2016 and 2017, respectively. These findings are in corroboration with those of Devi et al., (2017), Mokidue et al., (2011), Dubey et al.,(2010) and Poonia and Pithia (2010).

\section{Technology gap}

Yield of the crop under front line demonstration trials and potential yield of the crop was compared to estimate the yield gaps which were further categorized into technology and extension gaps (Hiremath and Nagaraju, 2009).The technology gap in the 
demonstration plots of Him Mash-I over potential yield were 5.69 and $4.46 \mathrm{q} \mathrm{ha}^{-1}$ and 4.60 and $3.23 \mathrm{q} \mathrm{ha}^{-1}$ in UG-218 during kharif2016 and2017, respectively (Table 2). The observed technology gap may be attributed to dissimilarity in soil fertility status, rainfall distribution, insect pest attacks as well as the change in the locations of demonstration plots every year (Mukherjee, 2003).

Table.1 Comparison between demonstration practices and existing practices under blackgram in Hamirpur District of Himachal Pradesh

\begin{tabular}{|c|c|c|c|}
\hline Sr.no. & Particulars & Demonstration practices & Existing farmers'practices \\
\hline 1 & Farming situation & Rain-fed & Rain-fed \\
\hline 2 & Variety & Him Mash-I \& UG-218 & Local Mash \\
\hline 3 & Time of sowing & $\mathrm{I}^{\mathrm{st}}$ fortnight of July & Mid-June \\
\hline 4 & Sowing method & Line sowing & Broadcasting \\
\hline 5 & Seed rate & $20 \mathrm{~kg} \mathrm{ha}^{-1}$ & $25-35 \mathrm{~kg} \mathrm{ha}^{-1}$ \\
\hline 6 & Seed treatment & Carbendazim @ 2.5 $\mathrm{gkg}^{-1}$ & No seed treatment \\
\hline 7 & Fertilizer dose & NPK@ @20:40:20 kg ha ${ }^{-1}$ & No fertilizers application \\
\hline 8 & Plant protection & Need based pesticide applications & No plant protection measures \\
\hline 9 & Technical guidance & Time to time & No technical guidance \\
\hline
\end{tabular}

Table.2 Productivity, technology gap, extension gap and technology index of black gram as grown under CFLD's vis-à-vis existing farmers' practices

\begin{tabular}{|c|c|c|c|c|c|c|c|c|c|}
\hline Crop/Variet & Year & $\begin{array}{l}\text { Area } \\
\text { (ha) }\end{array}$ & $\begin{array}{l}\text { No. of } \\
\text { farmers }\end{array}$ & \multicolumn{2}{|c|}{$\begin{array}{l}\text { Yield } \\
\text { qha }^{-1}\end{array}$} & $\begin{array}{l}\% \text { increase } \\
\text { over } \\
\text { local check }\end{array}$ & $\begin{array}{l}\text { Technology } \\
\text { gap } \\
\text { q ha }^{-1}\end{array}$ & $\begin{array}{l}\text { Extension } \\
\text { gap } \\
\text { q ha } \\
\end{array}$ & $\begin{array}{l}\text { Technology } \\
\text { index } \\
(\%)\end{array}$ \\
\hline & & & & Demons. & $\begin{array}{l}\text { Farmers } \\
\text { practice }\end{array}$ & & & & \\
\hline HimMash-I & Kharif & 0.7 & 4 & 6.31 & 4.84 & 30.8 & 5.69 & 1.47 & 47.4 \\
\hline UG-218 & 2016 & 6.0 & 44 & 5.40 & 4.73 & 14.2 & 4.60 & 0.67 & 46.0 \\
\hline HimMash-I & Kharif & 6.0 & 25 & 7.54 & 6.22 & 21.2 & 4.46 & 1.32 & 37.2 \\
\hline UG-218 & 2017 & 4.0 & 15 & 6.77 & 6.20 & 9.10 & 3.23 & 0.57 & 32.3 \\
\hline
\end{tabular}

Table.3 Gross returns, Net returns, Gross cost cultivation and B: C ratio of black gram as grown under CFLDs and existing farmers' practices

\begin{tabular}{|c|c|c|c|c|c|c|c|c|c|}
\hline \multirow[t]{2}{*}{ Variety } & \multirow[t]{2}{*}{ Season } & \multicolumn{2}{|c|}{$\begin{array}{l}\text { Gross cost of } \\
\text { cultivation } \\
\left(\text { Rs. }^{-1}\right)\end{array}$} & \multicolumn{2}{|c|}{$\begin{array}{l}\text { Gross returns } \\
\left(\text { Rs. ha }^{-1}\right)\end{array}$} & \multicolumn{2}{|c|}{$\begin{array}{l}\text { Net returns } \\
\left(\text { Rs. } \text { ha }^{-1}\right)\end{array}$} & \multicolumn{2}{|c|}{ B:C Ratio } \\
\hline & & Demons & Local & Demons. & Local & Demons. & Local & Demons. & Local \\
\hline HimMash-I & Kharif & 26500 & 24500 & 50480 & 38720 & 23980 & 14220 & 1.90 & 1.58 \\
\hline UG-218 & 2016 & 26500 & 24500 & 43200 & 37840 & 16700 & 13340 & 1.63 & 1.54 \\
\hline HimMash-I & Kharif & 26500 & 24500 & 60320 & 49760 & 33820 & 25260 & 2.27 & 2.03 \\
\hline UG-218 & 2017 & 26500 & 24500 & 54160 & 49600 & 27660 & 25100 & 2.04 & 2.02 \\
\hline
\end{tabular}


Photographs of field days on cluster front line demonstrations on blackgram in District Hamirpur (H.P.)

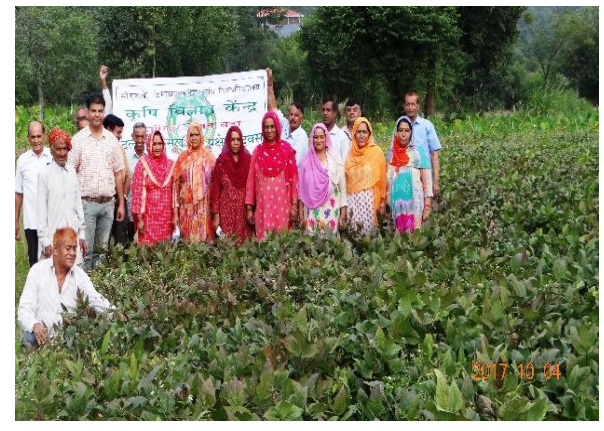

\section{Extension gap}

During kharif 2016 \&2017, the corresponding extension gap of 1.47 and $1.32 \mathrm{q} \mathrm{ha}^{-1}$ was recorded in Him Mash-I and 0.67 and $0.57 \mathrm{q}$ $\mathrm{ha}^{-1}$ was recorded in UG-218 over farmers' practice. This indicated the need to educate the farmers through various means for adopting improved agricultural production technologies to reverse this trend of wide extension gap.

Extensive use of latest production know-hows with improved high yielding variety will subsequently change this trend of extension gap. The adoption of newer technologies enables the farmers to discontinue their traditional practices (Table 2). Similar outcomes were also obtained in blackgram by Bairwa et al., (2013) in Rajasthan.

\section{Technology index}

The technology index of 47.4and 37.2per cent were recorded in Him Mash-I and 46and 32.3 per cent in UG-218 during kharif 2016 \& 2017, respectively (Table 2). The technology index illustrates the feasibility of the variety at the farmer's field. Lower the value of technology index, more is the feasibility of technology. This indicated a gap between technology evolved and technology adopted at farmer's field (Arunachalam, 2011 and Kumar et al, 2014).

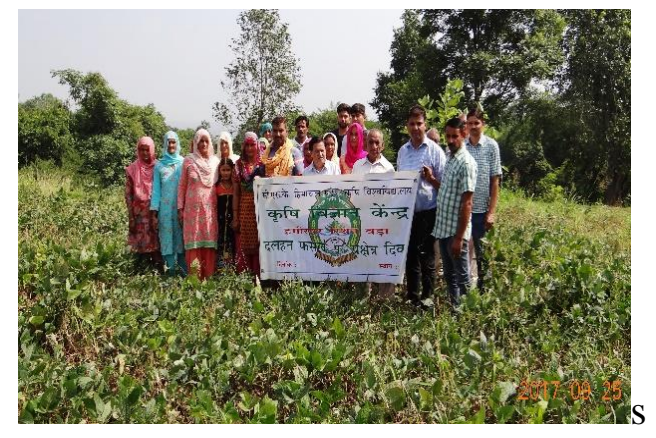

\section{Economics}

The input and output prices of commodities prevailed during the study of demonstrations were taken for calculating gross returns, cost of cultivation, net return and benefit: cost ratio (Table 3 ). The cultivation of blackgram varieties Him-Mash-I and UG-218 under improved technologies gave higher net returns of Rs. 23980, 33820 and 16700,27660ha ${ }^{-1}$ over farmers' practices, respectively. This may be due to higher yields obtained under improved technologies compared to local check (farmers' practices). Similar conclusion was reported by Mokidue et al., (2011). Benefit cost ratio of 1.90, 2.27 and 1.63,2.04 were recorded in Him Mash-I and UG-218, respectively during kharif 2016 and2017as compared to farmer practices $(1.58,2.03$ and $1.54,2.02)$ during the period of study. The data indicated the positive effect of front line demonstrations over the existing practices towards increasing the yield of blackgram. Parallel findings were obtained by Bairwa et al., (2013).

Hence, it can be concluded from the study that in front line demonstrations, increased seed yield and higher returns were registered through adoption of improved varieties and technologies as compared to the farmers' practices and thus FLDs played an important role in harvesting higher crop yield and returns. 


\section{References}

Arunachalam R. 2011. Spread and acceptance of recommended production technologies in greengram and black gram: a comparative analysis. Legume Res - An International Journal 34(1): 813.

Bairwa, R. K., S. R. Verma, K. Chayal and N.L. Meena 2013. Popularization of improved black gram production technology through Front line demonstration in humid southern plain of Rajasthan, Indian Journal of Extension Education and R.D. 21: 97101.

Chaudhary, B. N.1999. Krishi Vigyan Kendra- A guide for KVK managers. Division of Agricultural Extension, ICAR, pp. 73-78.

Dubey S, Tripathi S, Singh P and Sharma R. K. 2010. Yield gap analysis of black gram production through frontline demonstration, Journal of Progressive Agriculture. 1(1):42-44.

Hiremath SM and Nagaraju MV 2010. Evaluation of on front line demonstrations on the yield of chilli, Karnataka J. Agric. Sci., 23 (2):341342.

Islam M, Mohanty A K and Kumar. S. 2011. Correlation growth yield and adoption of urd-bean technologies. Indian Research Journal of Extension Education 11 (2): 20-24.

Kadian, K.S., Sharma, R. and Sharma, A.K.1997. Evaluation of frontline demonstrations trials on oilseed in Kangra valley of Himachal Pradesh. Annals of Agriculture Research, 18(1):40-43.

Kumar S, Singh R and Singh A. 2014. Assessment of gaps in pulse production in Hamipur district of Himachal Pradesh. Indian Research Journal of Extension Education 14(2): 20-24

Devi, M. Ganga, Choudhry, A.K., and Srinivas D. K., 2017. Journal of Krishi Vigyan, 6(1): 97-100.

Mokidue, I., Mohanty, A.K. and Sanjay, K. (2011). Correlating growth, yield and adoption of urd bean technologies. Indian Journal of Extension Education. 11(2): 20-24.

Mukherjee, N. (2003). Participatory, learning, action and concept, Publishing Company, New Delhi, pp. 63-65.

Poonia TC and Pithia MS 2011. Impact of front line demonstrations of chickpea in Gujarat. Legume Research, 34(4): 304307

Samui, S. K., Maitra, S., Roy, D. K., Mandal, A. K. and Saha, D. (2000). Evaluation of front line demonstration on groundnut. Journal of Indian Society of coastal Agricultural Research, 18(2): 180-183.

Singh A.K., Gautam U.S., Chahal V.P., Singh N.P., Singh Atar, Dubey S.K. and Yemul S.N. 2016. Demonstrational performance of pulses in India: Experiences of KVKs under NFSM (2015-16) 122p.

\section{How to cite this article:}

Dhanbir Singh. 2020. Yield Gap Analysis through Cluster Front Line Demonstrations on Blackgram in Hamirpur District of Himachal Pradesh, India. Int.J.Curr.Microbiol.App.Sci. 9(11): 2493-2498. doi: https://doi.org/10.20546/ijcmas.2020.911.301 